\title{
Global challenges in securing equity and human rights: Re-envisioning the role for evaluation in the contemporary HIV/AIDS epidemic
}

\section{Robin Lin Miller}

Keynote Address for ANZEA 2021 Virtual Conference

22 March 2021

Kia ora. It is an honour to join you in this important discussion of evaluation's role and contribution to creating equitable societies. I am speaking to you from my current hometown of Okemos, Michigan, in the United States (US) rather than, as I had hoped, in a conference meeting room in Rotorua. Okemos is rightfully Ojibwe tribal land. Chief Okemos, after whom the town is named, was the Ojibwe chief who represented his people when they, along with the Ottawa and Potawatomi, were forced to yield their territory to the US government in the 1819 Treaty of Saginaw. Michigan State University also sits on the forcibly surrendered lands of the Three Fires Confederacy.

My ancestral history well reflects my country's colonial settler heritage. In the fall of 1638, my ninth great-grandfather, William 
Boynton, along with his wife Elizabeth, their first three children, and William's brother's family, departed East Riding in Yorkshire, England on the ship John of London to settle in the Massachusetts colonies. They were among 20 families crossing the Atlantic as followers of the Reverend Ezekial Rogers, a pastor suspended for his non-conformist Puritan beliefs. The Boynton family settled in Pennacook tribal territory on the Reverend's plantation which was soon thereafter established as the town of Rowley (Blodgett, 1887; Boynton \& Boynton, n.d.; Gage, 1840; Tracy, 1878). William served as Rowley's first schoolmaster. My great-grandfather rapidly amassed property, leaving each of his 11 children sizeable farms by the time of his death in $1686 .{ }^{1}$ By the early 1700 s, his descendants had migrated to other parts of the Pennacook homelands in New England. My sixth great-grandfather, John, re-settled his family to New Hampshire on a 75-acre farm granted to him by King George situated not far from the banks of Lake Waukewan, a farmstead that remained in my family from roughly 1727 until about 14 years ago. ${ }^{2}$

In 1895, one of William's many descendants and heir to that farm, Gertrude Boynton Ames, married a young Scotsman named Kenneth Miller. Kenneth had recently arrived in the US from Wick, County Caithness, a small coastal village located in the northeast Scottish Highlands, where his family had drawn their livelihood from the sea for generations (J. Miller, 1979, 1994). He established himself in the US as a baker, eventually taking over a local bakery. Kenneth and Gertrude's only child, my paternal grandfather Sutherland, married a woman of Swedish and French-German descent, Jesse Cleone

1 Most historical records list William's date of death as 8 December 1686. However, Thomas Gage's history of Rowley lists his year of death as 1665 .

2 After my father's death, I inherited extensive records and original documents (e.g., naturalisation papers, letters to and from people who remained in homeland countries). I rely heavily on those records here, in addition to ongoing genealogical research performed by me and family members here and in Scotland, and on stories told, and no doubt embellished, by family members. 
Gasser. Cleone's grandfather, Nils Ellstrom and his wife, Anna Louise Safe, left Älvsbacka, Värmland in Central Sweden for Rock Island, Illinois in 1879, part of a wave of Swedish resettlement to the upper Midwest driven by the quest for farmland and better employment opportunities. Nils made his living flipping houses, which no doubt influenced my great-grandmother Hilma-who changed her name to Jacqueline to sound appropriately American - to become the first female licensed real estate agent in the state of Iowa. I know little of grandmother Cleone's paternal ancestry except that the family comes from the French-German border region of Alsace-Lorraine. Despite this gap in my knowledge, it is fair to say that my father's ancestral history reflects the common narratives of the Europeans who settled here. His people came in hope of opportunity, eager to escape what they perceived as untenable economic or oppressive religious circumstances, thinking less of the impact of their arrival here on those who occupied the land before them than of their own future possibilities.

My mother's family reflects my country's unique colonial settler history too. My mother's ancestors are among the thousands of enslaved Africans brought to Virginia and the Carolinas from land we now know as Guinea-Bissau. ${ }^{3}$ Like most people of African descent in the US, I know little about them before the period surrounding the Civil War except what is handed down to me in story. If you input any of my family members' names into a genealogical website like Ancestry.com, the names on my father's side of the family sprout dense clusters of green leaves symbolising the presence of voluminous records extending back 10 generations or more. The names on my mother's branches remain mostly bare, an occasional leaf sprouting here or there. Until the first two censuses following the emancipation

3 I again rely here on my own research and inherited records, research conducted by my many McLain-Naudin-Dibble-Palmer-descended cousins, sources such as www.enslaved.org and www. slavevoyages.org, and genetic testing provided by companies specialising in tribal genetic analyses of formerly enslaved people. 
of slaves in 1865, the presence of most Blacks in the US was recorded only as a first name, sex, age on a slave schedule, or in the notice of bounty put on the head of a runaway. I am, however, luckier than many Black people in the US. I can trace my ancestors to specific towns going back about 45 years before emancipation. During the 1840s, my third great-grandmother Leah bore a child at age 15 to a man who was the master or an heir to the Palmer plantation where her family was enslaved. My third great-grandmother Jane bore a mixed-race son around the same time. My family were house slaves by and large, roles among the enslaved that helped launch them into the Black upper middle classes post-emancipation. Several of my second great-grandparents could read and write despite the vigorously enforced anti-literacy laws of that era. My great-grandparents fled to New York and Massachusetts during the earliest years of the Great Migration. During that period, Blacks left the South in droves to blunt the effects of de jure segregation under Jim Crow and to escape the daily violence enacted with impunity by Whites on Black people. The North was better, certainly, but no escape from de facto segregation, which routinely assaulted Blacks' dignity and value outside the safety of Black society.

Jim Crow laws prevailed when my parents married and throughout my early childhood. My parents' constitutional right to marry was not established until they had been married for 6.5 years (Loving v. Virgina 388 US 1, 1967). More than 70\% of Americans opposed interracial marriage at that time, according to national polls (Saad, 2017). When I was born in Connecticut in 1961, the US continued to operate under the rules set in place to support its peculiar preoccupation with false notions of white superiority and racial purity. Consistent with the rules and structures designed to keep the races separate and unequal, my birth certificate identifies me as Negro. It has always been this way in the US. We organise ourselves into 
categories manufactured in the stifling horror of slave-ships' bellies plying the Atlantic, categories created to reinforce a baseless certainty that some people are inherently and immutably superior to others.

In some fundamental sense, my blue eyes, fair complexion, and blondish hair highlight the absurdity of the US caste system. To look at me, you would never assume that my maternal DNA is of the Balanta tribe of Senegambia. Yet, appearance and identity are independent of one another for thousands and thousands of mixed-race people like me who have been part of the US Black community since our earliest presence here. We are of all shades and of diverse experiences. Among my mother's gifts to her children was to embrace a proud, resilient Black identity, one it would never occur to us to deny by passing as White. Passing, as the writer Thomas Chatterton Williams observes, and I quote, "pretends to subvert but ultimately merely upholds the rules of an unjust game" (Williams, 2019). I have never conceived of the privilege of my complexion, my partial European ancestry, and my elite social class standing as a contradiction to Blackness. Identifying as Black is an embrace of my African ancestors who made my life possible and the collective memory that I inherit from them.

Existing in a middle position of ambiguity and paradox, betwixt and between colonisers and colonised, advantaged but not equal, established my intense interest in how the structures of inequality are made and maintained. My simultaneously fierce yet attenuated sense of belonging to each world drove a deep fascination in the very different views one may have on a single course of events. It is perhaps that deep interest in what sense people make of one another and the social arrangements and rules that advantage some at the expense of others that drew me to evaluation and to the specific work that has been the core of my practice for the past 35 years. It also informs my hopes for our field. I want evaluation to be a force for broad structural change. I believe evaluators have an important role to play in generating 
coherent and cohesive accounts of how programmes and policies are experienced by those who are the least advantaged and powerful in society. We can shed light on how programmes and policies impact on diversity, equity, and inclusion. We can render evidence-informed judgements of whether programmes and policies reinforce or transform the status quo.

My social position shapes my hope and desire for a form of evaluation practice that centres on the diverse experiences and understandings of people who live in the shadows of power. It provides clues as to why I aspire to a manner of practice that contributes to changing the structures that marginalise and dehumanise. It explains why I elected to earn my doctorate in community psychology, a not-widelyknown subdiscipline of psychology that centres its practice on principles of collaboration and community empowerment and its purposes on the attainment of justice and equity for oppressed peoples. In what remains of this article, I will argue that to attain equitable evaluation practices requires that we grapple with the thorny paradoxes and ambiguities in our current theories of practice. Equity-oriented practices have been brewing in evaluation for some time, yet we are still early in learning how guidance on practice plays out when we seek to navigate in novel contexts. I will illustrate why more complete exploration of the contradictions, risks, and ambiguities in our models of practice requires our thoughtful attention through a brief exploration of a recent evaluation project studying AIDS activists in parts of the global South. I will conclude by suggesting that, to support the quest for equitable societies through evaluation, we must shift our focus from elaborating tools and techniques to examining our professional and personal commitments to societal reform. We must confront how we see ourselves and our proper role as evaluation professionals if we are to move closer to a world in which we aspire to live. 
We have journeyed incredibly far in reimagining whether and how evaluators can contribute to social equity. We have adopted perspectives that are culturally responsive, we have articulated approaches to practice that support oppressed communities' self-determination and emancipation, and we have learnt from those outside our field how we might transform evaluation to transform society. The rapid development of culturally responsive evaluation provides one example of how far we have come. Culturally responsive evaluation asks that we ground our work in local traditions and ways of producing knowledge. It suggests that the ways of understanding social problems and their appropriate solutions should originate in the communities most burdened by them. A central aim of privileging indigenous alternatives is to decolonise evaluation by revealing the cultural assumptions underlying Western evaluation methods and practices and by advocating for parity with the knowledge traditions and forms of wisdom native to other contexts and traditions. In effect, a culturally responsive and emancipatory practice demands of us that we understand the potential for evaluation itself to become a colonising social process. In the introduction to the re-issue of poet and activist Aimé Césaire's classic book, Discourse on Colonialism, the scholar Robin D. G. Kelley writes:

We are hardly in a postcolonial moment. The official apparatus might have been removed, but the political, economic, and cultural links established by colonial domination still remain with some alterations ... The lesson here is that colonial domination required a whole way of thinking, a discourse in which everything that is advanced, good, and civilized is defined and measured in European terms. (Kelley, 2001, p. 27)

Despite how far we have come, this remains among our defining challenges. 
The data journalist Mona Chalabi suggests that our human biases are revealed in data. Data replicate systems of power because the questions we pose and the types of data we collect to answer those questions reflect the interests of the powerful. The structures of oppression dictate whose opinions and perspectives bear the greatest weight. Evaluators can and have been a witting and unwitting partner in this process. It remains that it is typically the powerful who commission evaluations and who pose the questions, which may exclude the perspectives of those who are burdened by inequity. The powerful almost always determine what gets evaluated and what does not (Rogers, 2016) and at what level of investment, reinforcing the status quo of social privilege and power.

My own practice has been a mix of evaluations commissioned by institutions steeped in resources and power, including governments and hospitals, but mostly it has comprised evaluations commissioned by community-led institutions. I began my career as an evaluator at the Gay Men's Health Crisis (GMHC), the first AIDS-focused advocacy and civil society organisation in the world. GMHC was born in the late activist Larry Kramer's living room to mobilise a response to what was then termed "gay-related immune deficiency" or GRID. The year I started at GMHC_-1987-the first drug to treat HIV, AZT, was approved by the US Food and Drug Administration. Condoms had not yet been demonstrated as an effective means of preventing HIV acquisition. US President Ronald Reagan, driven by stigma and fear, enacted policy prohibiting HIV-infected travellers into the US. The AIDS Quilt was being prepared for its debut on the National Mall in Washington DC, comprising 8,288 panels, far smaller than today's 54-ton hand-stitched memorial.

The era during which I worked at GMHC was remarkable for the passionate advocacy work occurring in New York (France, 2016) and in other hard-hit cities around the world, advocacy driven by a 
profound desperation at the indifference of the larger world to the devastation witnessed daily in the lives of people affected by HIV. As the lead evaluator for our prevention and education units and later as the founding director of our first agency-wide Department of Evaluation, I conducted multiple internal evaluations of diverse homegrown programmes and advocacy efforts to address the rapidly advancing epidemic. Evaluation textbooks of the era provided me little guidance. My colleagues and I intuitively built and adapted evaluation approaches and designs as we went, however imperfect, in hope of being useful in the face of tremendous uncertainty. Death urged our work forward.

At a global level, 75.7 million people have been infected with HIV since the epidemic was first identified (UNAIDS, 2021a). The epidemic has laid claim to an estimated 32.7 million lives. In 2016, the global public health community established ambitious global targets to end the epidemic by 2030. By 2018, it was clear we were far behind and would fail to meet the goals for 2020 (Marsh et al., 2019). Fail we did. For evaluators concerned about equity, our failure is instructive. We are most behind in meeting the needs of the highest risk and most stigmatised populations impacted by HIV, euphemistically referred to as the key populations: gay, bisexual, and other men who have sex with men; sex workers; transgender people; injection drug users; and the incarcerated. In 2019, these five groups of people accounted for $62 \%$ of new infections globally (UNAIDS, 2020a). Moreover, they are the largest share of new infections in every region of the world save one. Stunningly, while new infections have declined in general over the past decade, including in some key population groups, they have increased 25\% among gay and bisexual men and 5\% among transgender people during the same period (UNAIDS, 2020b). COVID-19 is expected to make the picture worse. The Global Fund estimated last summer that the COVID-19 
pandemic was likely to set the fight against AIDS back roughly a decade (The Global Fund, 2020).

Human rights violations and entrenched stigma and discrimination are widely understood as a key driver of the international community's failure to meet the targets for ending the HIV epidemic (UNAIDS, 2020c, 2021b). Countries in Africa loom large as the sites of the kind of homophobic human rights violations that fuel epidemics. It is also here where recent projections suggest we are most likely to fail in meeting targets for the epidemic's end. Pervasive stigma and discrimination in all domains of daily life continue to have pernicious effects on gay and bisexual men's and transgender women's ability to access affirming HIV prevention, testing, and treatment and to providers' ability to offer it. Until countries everywhere better address their health-care needs and actively address stigma and discrimination against these populations, an AIDS-free generation will remain impossible to attain.

African nations are highly dependent on development aid to address their HIV epidemics (UNAIDS, 2020c; Wamai, 2014). Despite international efforts over the past 10 years to push more of these funds toward addressing the needs of the gay and bisexual community and to support community-led responses, little spending ultimately goes here (Avert, 2021). Studies suggest that, although gay and bisexual men made up roughly $20 \%$ of new infections globally between 2016 and 2018, funding to address their needs comprised $1 \%$ of the $\$ 57$ billion dollars donors directed at the epidemic (AidsFonds, 2020).

Sexual and gender minority human rights are a salient aspect of global politics. Yet, throughout the African diaspora, homophobia and transphobia are part of a complex postcolonial dynamic (Aldrich, 2003; Epprecht, 2008, 2010, 2012; McKay, 2016; Semugoma et al., 2012). Western countries have built an alliance around the idea that 
human rights are universal and should extend to sexual and gender minority people. The commitment to protecting the human rights of sexual and gender minority people has sown sharp divisions that are played out in the context of development aid (Currier \& Cruz, 2014; Onapajo \& Isike, 2016). Development aid is viewed by some as the West's cudgel to move Catholic, Muslim, and Evangelical countries to a more accepting view. Scholars of the diaspora suggest that the claim to universal human rights frames the West's liberal ideas around sexual and gender minority people as significantly more enlightened, echoing the patronising colonial attempts to "civilize" Africa (Rao, 2014). In this discourse, homosexuality is a colonial import imposed on nations in the African diaspora and elsewhere as part of the assertion of the West's superior values and beliefs. Public moral codes condemning of homosexuality in Africa are colonial in their language and origins (although in some cases these laws were established or strengthened after African nations gained their independence), leading to the counter-assertion that what the West imposed on Africa is not homosexuality, but homophobia.

Western nations have increasingly used sexual and gender minority human rights as a condition of development aid. African political leaders have pushed back against these contingencies as attempts at colonial domination. Among the more famous examples of open defiance of the West's attempt to promote sexual and gender minority human rights is Robert Mugabe's 2011 radio address in which he asserted that homosexuals are "worse than pigs and dogs", in response to David Cameron conditioning British foreign aid on Zimbabwean tolerance of homosexuality. Here is the President of Gambia making a similar rebuff in 2014:

We will fight these vermin called homosexuals or gays the same way we are fighting malaria-causing mosquitoes, if not more aggressively ... We will therefore not accept any friendship, aid or any other 
gesture that is conditional on accepting homosexuals or LGBT as they are now baptized by the powers that promote them. (Cited in Onapajo \& Isike, 2016, p. 22)

In this context, offering HIV services to gay and bisexual men and transgender people becomes a dangerous proposition. Civilsociety organisations and their clinics' offices are routinely vandalised (The Global Forum on MSM and HIV, 2015; Semugoma et al., 2012). Their workers' lives are put at risk simply by attempting to provide the most basic of HIV care. For example, an incredibly violent summer in Cameroon led to the suspension of services at four agencies and the brutal murder of the newly named Executive Director of CAMFAIDS, which is a leading HIV/AIDS non-governmental organisation in Yaoundé, the capital city. Eric Lembembe was found in his home with his feet and hands bound, his feet and neck broken, and his face, hands, and feet scorched with an iron. Murders such as his are commonplace.

In many countries, the only path to legal recognition for sexual and gender minority human-rights organisations permitting them to receive foreign aid and have a bank account is to register as an HIV organisation and take on the programming work dictated by the HIV international donor community (Currier \& Cruz, 2014), which ultimately deflects programming and evaluation attention away from their work as agents of structural change to end discrimination (Currier \& Cruz, 2014; Currier \& McKay, 2017). What gets evaluated in this space by and large is not advocacy or other organised efforts to address the stigma and discrimination that undermines access to HIV prevention, testing, and care. Instead, what gets monitored are outputs such as HIV test distribution, which is important certainly, but is not at the root of what local communities demand (Burger \& Seabe, 2014): the ability to access fundamental rights and be viewed as rights holders. 
The potential role for equity-focused evaluation here is clear. Our professional community is uniquely positioned to evaluate efforts to reduce stigma, discrimination, and violence, and eliminate barriers to HIV care in these contexts. But it is not a space where many evaluators tread or where evaluations are frequently commissioned. The risk to local evaluators for taking on this work is high. For the outside evaluator, the risks are high, too, but they differ. Our quest for a decolonising form of practice collides with our shared beliefs in defending the sovereign rights of independent nations. Our professional desire to ensure that indigenous value systems are not undermined by the West clash with our desire to attain equitable ends for sexual and gender minority people. Our sensitivity to "avoid[ing] the mindless, and/or context-divorced application of critical notions such as 'democracy', 'human rights' and 'equity'” (Ofir, 2012) are at odds with what evidence suggests regarding the disproportionate burden of HIV on sexual and gender minority communities. The overemphasis on donor-driven accountability-focused monitoring of HIV testing and provision of biomedical treatments will not get us far, nor will strategies that disregard what communities believe are required to help them attain equitable ends. The importance of identifying evaluation strategies that are viable, respectful, useful, and equitable is urgent.

Three years ago, I decided that I wanted to better understand what evaluation practice might look like under these challenging conditions. I wanted to gain richer insight into what it might mean for equitable practice to confront the complex contradictions illuminated in this space. I wrote to an old activist friend about the possibility of working with him for a year to explore these issues. My friend, George Ayala, ran a group named MPact. Founded in 2006, MPact leads networks of activists in 62 countries to advocate for equitable access to effective HIV prevention, care, treatment, and 
support services for gay men and bisexual men, including those living with HIV, and promotes their health and human rights through advocacy to transnational policy bodies such as the United Nations and the World Health Organization. Within moments of hitting "send" on my email to George, he replied. "When can you get here?"

Immediately before my first day with MPact, the organisation received a sizeable grant from the Elton John AIDS Foundation, US President's Emergency Plan for AIDS Relief, and USAID. The timing of the grant was entirely unexpected and MPact was not prepared for the cash when it suddenly arrived after a 2-year delay. Caught up in the fast-paced startup, George proposed we use that grant to explore evaluation issues. Project ACT became our learning laboratory.

A 20-month demonstration, Project ACT's objective was to employ diverse advocacy tactics to remove barriers to access to HIV care among gay, bisexual, and transgender women in Africa and the Caribbean (Miller et al., 2021). The project operated on a partnership model between MPact and seven small sexual and gender minority-led organisations in Sub-Saharan Africa and the Caribbean. The project also sought to enhance the advocacy capacity of these partner organisations. The partners are in African and Caribbean countries that are characterised by poorly managed HIV epidemics among gay and bisexual men and transgender women and that possess hostile social and political climates toward the human rights of sexual minority and gender non-conforming people (Flores, 2019). Most criminalise homosexuality or use public-decency laws to that effect (Mendos, 2019). Several are notorious for their egregious humanrights violations and violence targeting sexual and gender minority citizens (Human Rights Watch Country Profiles, 2020; United States Department of State, 2019). The project's advocacy strategies for improving access to care were to challenge policy and legal barriers, reduce stigma and discrimination, and eliminate violence and 
threats to security. The specific advocacy targets and tactics each partner selected were chosen to suit their context and constituents' perceived needs. In the end, every country did something unique.

Few of these partners had any evaluation experience or capacity. What experience they did have was negative. In their experience, evaluation was used by international donors in a punitive manner; they were seldom allowed to focus on indicators that were responsive to and meaningful for constituents. Few had seen an evaluator in person. By and large, evaluators sat in their offices in London or Amsterdam or Washington, never having set toe on the ground. Among the most important of our initial decisions regarded how to position me relative to the work and the partners. I became an embedded member of the lead advocate team at MPact. George and I believed embedding the evaluation role in the team was essential to being trusted as an ally by the partners, to feeding evidence into the work most usefully, and to ensuring a level of responsibility for the work that was appropriate to its seriousness. We set out to document MPact's contributions to country-level progress toward the project's vision, examine its negotiation of the Global-North-Global-South dynamics, describe what the work looked like on the ground, and to report on and learn from the project's challenges, successes, and achievements. We decided that an equitable evaluation should seek first and foremost to contribute to the nurturance of context-appropriate advocacy leadership, evidence-informed reflection, and MPact's transparent accountability to its global networks of advocates.

Initiatives such as Project ACT intend to enhance the contributions of networks of advocates and their allies to achieve humanrights aims; in this case, tearing down the barriers that create inequitable access to HIV care. As partners mobilise civil society and the constituencies to whom they are beholden, influence the media, and compel others to champion the causes they pursue, all who are 
mobilised in a common cause play a role in pushing change forward. Initiatives such as Project ACT are therefore not amenable to designs that seek to isolate a presumed sole cause of a simple and easily discerned effect or to approaches employing inflexible designs (Gardner \& Brindis, 2017; Schlangen, 2014; Teles \& Schmitt, 2011). Rather, the task is to build on logic and evidence to make plausible connections between what advocates do and outcomes that emerge. Flexible, emergent, and nimble designs work best because the evaluator can respond to the inevitable changes that occur in advocacy without undermining the evaluation's rigor or integrity (van Wessel, 2018). These designs free us from using designs that some might characterise as having a distinctly Western signature. The hope of painting a picture of advocacy in these contexts-showing what the quest for equity requires - guided our design decisions.

Protecting and promoting human rights is worth doing without the kind of evidence of tangible gains funders typically prefer (Schlangen, 2014). Setbacks and blowback are inevitable and may occur more often than progress. Lack of evidence of forward momentum or evidence of backwards steps do not bear on the moral value of the work. If evaluators are seriously committed to equity, pushing our clients and development funders to think about appropriate signposts of success is key (Arensman, 2020; Arensman \& van Wessel, 2018). MPact's values regarding partnerships reflect deep sensitivity to the colonising dynamics that might emerge from their position as a donor and technical-support provider from the global North. MPact staff rightly and openly worry about how to conduct their work in ways that respect and support the local expertise of project partners. Most of the staff and board are from the global South and cut their teeth as advocates in these regions of the world. They are keenly aware that activists in the global South are not waiting around to be rescued by people from the Global North. They do not believe that 
Western-styled advocacy is necessarily wise or appropriate, especially given that much of this work is occurring in non-democratic country environments. At the same time, staff are cognizant that local cultures produce the very social inequities that this project intended to critique. In combination, MPact's stance and the importance of not imposing Western expectations on advocacy in these contexts guided us to prioritise understanding what the local actors in these countries perceived as meaningful steps forward or backward and how they made sense of the political, social, economic, and cultural context as influencing steps toward equitable access.

We established it as core operating principles to honour and respect the dignity and self-worth of partners and their constituents and to honour and respect their local knowledge and expertise. We assumed that activists knew how to manage their visibility and what values and strategies made sense for their constituents and environment. We strived to operate throughout our work together from a place of what the journalist and scholar Isabel Wilkerson terms radical empathy (Wilkerson, 2020). Radical empathy, she says, is not the ordinary task of imagining oneself in the shoes of another. It is the opening of your spirit to the pain of others as they perceive that pain (Stauffer, 2015). It is a form of witnessing. It also involves identifying the narratives and counter-frames to the dominant narratives of worthlessness (Feagin, 2020). It celebrates and highlights resilience. The root of radical empathy is the dignity and value of all people. From an evaluation standpoint, one example of what this required was that we centre data-collection techniques in ways that were radical in their empathy rather than rational and distancing in their construction. Our interviews in country centred on this notion. We relied on feminist and transformative interviewing approaches and observed an ethic of caring (Campbell, 2002; Nelson \& Evans, 2014; Oakley, 1981; Roulston, 2010). This proved important because 
of the tremendous trauma advocates had experienced personally or in handling local cases of rights violations.

We created routine opportunities for critical reflection and team dialogues throughout all phases of the project at the level of the MPact team, the transnational project team, and in each country team. These routine touch points were structured as opportunities for re-assessment, dissent, and dialogue and as part of the building of a learning community at all levels of the project. They also assisted us in ensuring that the evaluation supported the advocacy. A key piece of this part of the project was transparency about how evaluation data were being used as we went along. Partners always knew what feedback was provided to MPact and how MPact intended to respond to it to enhance the country-level work.

A limitation of the literature on advocacy evaluation is that it is oriented largely toward Western liberal democracies in which citizens may advocate for change without risking their most basic freedoms and right to personal safety. Human-rights workers operate in fraught and contested spaces (Mulé, 2018). Their work is dangerous. They must manage their visibility carefully (Currier, 2012, 2019). Their online communications are surveilled. They lack a virtual presence purposefully. Workers are tailed and harassed by the police. Some do their work under pseudonyms. They risk arrest on charges of subversion. As one of the partners observed, "We've had the same President for 36 years. He doesn't want noise. He will crush it." In that same interview, he noted a baby elephant cannot defeat an adult: "You have to respect the position of the adult ... This is Africa." The potential of outsiders to undermine local efforts and do irrevocable harm to advocates, their constituents, and the work is great (CorreyBoulet, 2019; Lorway, 2015).

Safety and the protection of human-rights advocates was a key consideration at every step of the work. A foundational principle 
guiding us was that we assess the risks to the safety and security of all involved and consider how evaluation activities and results might set back current efforts. We made concrete steps to mitigate those risks and relied heavily on our partners to ensure that our risk-mitigation efforts were acceptable and known to those at the highest risk. We spent considerable time discussing the unique security situation in every country, covering everything from police surveillance to safe language for my visa applications to data collection and dissemination practices. We decided, for example, not to make an evaluation visit to one country because of the risk it posed to activists. In the highest risk countries, I was never told where I was going or whom I was meeting with until I arrived. I turned off WiFi, bluetooth-enabled, and cellular services on my phone once I left my local lodging to prevent my location from being tracked. I travelled without a computer. These and many other steps we took were critically important because I knew about advocacy actions that had not yet occurred and were in the planning stages. I met with activists whose link to this work may not have been known by the government. In Cameroon, for instance, I knew that activists were surveilling three health districts and sending in people covertly to document stigma and discrimination (Miller, 2020). They were doing incredibly dangerous work. I conceived of my role as to enhance and protect those people and that work, even if I brought a critical eye to it and asked difficult questions about it.

In data collection, we prioritised the needs and concerns of the most marginalised and excluded. For example, we focused on gendered norms that undercut the rights of transgender women and paid close attention to how inequities based on gender were being reproduced by project procedures. I spent considerable time talking to the people sent into hospitals covertly in Cameroon about what that work was like and the adequacy of the protections the project 
provided to them to do it. Transgender women were placed in greater danger by the procedures in place than were gay men. By focusing on how decisions, actions, and choices that left transgender women's perspectives on safety out of the procedures, we were able to reduce inequities in the project's basic operation and include the community in its redesign. As one of the transgender activists said in my final interview with her, "By including us, we could better understand the project and own it. Don't do it for us. Do it with us." Communityled efforts to attain equity have multiple defining features, but most notably accountability to constituents, not donors. An activist form of evaluation infused with radical empathy is one that supports transparent mechanisms of accountability to those constituents. It pursues perspectives on society's policies and programmes that are centered in communities rather than solely in the mindscapes that guide those who are officially vested with responsibility to forge and implement responses to societal problems. It recognises that it is simply too easy for evaluators to look only at the pace, path, and terms of success as these are set by the societal institutions that maintain the status quo.

How do evaluators become better allies? In some ways, this should be easy for us. We are disposed toward critical analysis. We are committed to claims-making that is well-warranted in evidence. We are skilled in drawing out and negotiating diverse value perspectives. We are attentive to cultural humility. We have models of practice to follow that are transformative and equity focused. We believe that a better world is possible. We recognise the value in divergent thinking on social problems. Effective equity evaluation requires each of these things. The question of what we need is less about tools and more about our dispositions toward activism. Are we willing to change where power is centred in evaluations? Are we willing to ensure that those who are marginalised become the authority over their own experiences? Effective allyship is a matter of principle and of 
challenging the existing power dynamics (Prilleltensky, 2003, 2008; Russell \& Bohan, 2016); it positions the marginalised at the centre of the evaluation at every level. The evaluator is their instrument; they are not ours. The evaluator's aim is to protect their interests. The evaluator's attention is not on what information powerful people claim to need, but on the evidence that supports the agency of the people without power to advocate, to craft a new future, and to realise equitable societies on the terms that they define.

\section{Acknowledgements}

I am grateful to Sonia Arreola, George Ayala, Omar Baños, Lily May Catanes, Angel Fabian, Sherrie Hicks, Stephen Leonelli, Johnasies McGraw, Nadia Rafif, Mohan Sundararaj, Greg Tartaglione, Johnny Tohme, and Zamora for welcoming me so warmly to MPact's Project ACT team and, although I do not name them here to protect their security, to the transnational Project ACT partners and their constituents; to my translators Melodie Bamén, Tatiana Bustos, Rosaura Dominguez, David Figueroamartin, Jean Kayitsinga, Alassane Touré, Jack Weyhrich, and Raymond Young; to the volunteers who helped me transcribe audio-taped interviews, Sarah Alabdali, Rachael Bailey, Maeve Denshaw, Gabrielle Grace, Lasya Marla, Brynn Muehlenberg, Alex Pawlaczyk, Sarah Raider, Jaleah Rutledge, Rachel Weber, Cameron Wilson, and Zoe Xu; and to Miles A. McNall, Donna R. Podems, and Giovanni Dazzo for their insightful feedback on earlier drafts of this address.

\section{References}

AidsFonds. (2020). Fast-track or off track? How insufficient funding for key populations jeopardises ending AIDS by 2030. https://aidsfonds.org/assets/ work/file/Fast-Track\%20or\%20Off\%20Track\%20report-final_0.pdf. Aldrich, R. (2003). Colonialism and homosexuality. Routledge. 
Arensman, B. (2020). Advocacy outcomes are not self-evident: The quest for outcome identification. American Journal of Evaluation, 41, 216-233. https://doi.org/10.1177/1098214019855137

Arensman, B., \& van Wessel, M. (2018). Negotiating effectiveness in transnational advocacy evaluation. Evaluation, 24, 51-68. https://oi. org/10.1177/1356389017733210

Avert. (2020). Funding for HIV and AIDS. https://www.avert.org/ professionals/hiv-around-world/global-response/funding.

Blodgett, G. B. (1887). Early settlers of Rowley, Massachusetts. The Essex Institute.

Boynton, J. F., \& Boynton, C. H. (n.d.). The Boynton family, volume 1: A genealogy of the descendants of William and John Boynton who emigrated from Yorkshire, England in 1638 and settled at Rowley, Essex County, Massachusetts. Forgotten Books.

Burger, R., \& Seabe, D. (2014). NGO accountability in Africa. In E. Obadare (Ed.), The handbook of civil society in Africa (pp. 77-91). Springer. https://doi.org/10.1007/978-1-4614-8262-8_6

Campbell, R. (2002). Emotionally involved: The impact of researching rape. Routledge.

Correy-Boulet, R. (2019). Love falls on us: A story of American ideas and African LGBT lives. Zed Books. https://doi.org/10.5040/9781350221208

Currier, A. (2012). Out in Africa: LGBT organizing in Namibia and South Africa. University of Minnesota Press. https://doi.org/10.5749/ minnesota/9780816678006.001.0001

Currier, A. (2019). Politicizing sex in contemporary Africa: Homophobia in Malawi. Cambridge University Press. https://doi. org/10.1017/9781108551984

Currier, A., \& Cruz, J. M. (2014). Civil society and sexual struggles in Africa. In E. Odabare (Ed.), The handbook of civil society in Africa (pp. 337-360). Springer. https://doi.org/10.1007/978-1-4614-8262-8_20

Currier, A., \& McKay, T. (2017). Pursuing social justice through public 
health: Gender and sexual diversity activism in Malawi. Critical African Studies, 9, 71-90. https://doi.org/10.1080/21681392.2017.1283637

Epprecht, M. (2008). Heterosexual Africa? The history of an idea from the age of exploration to the age of AIDS. University of Ohio Press.

Epprecht, M. (2010). The making of 'African sexuality': Early sources, current debates. History Compass, 8, 768-779. https://doi. org/10.1111/j.1478-0542.2010.00715.x

Epprecht, M. (2012). Sexual minorities, human rights, and public health strategies in Africa. African Affairs, 111, 223-243. https://doi.org/10.1093/ afraf/ads019

Feagin, J. R. (2020). The white racial frame: Centuries of racial framing and counter-framing (3rd ed.). Routledge. https://doi. org/10.4324/9780429353246

Flores A. R. (2019). Social acceptance of LGBT people in 174 countries, 1981 to 2017. UCLA School of Law Williams Institute.

France, D. (2016). How to survive a plague: The inside story of how citizens and science tamed AIDS. Knopf.

Gage, T. (1840). The history of Rowley, anciently including Bradford, Boxford, and Georgetown, from the year 1639 to the present time. Ferdinand Andre'VS.

Gardner, A. L., \& Brindis, C. D. (2017). Advocacy and policy change evaluation: Theory and practice. Stanford University Press.

Global Forum on MSM \& HIV, The. (2015). Services under siege: The impact of anti-LGBT violence on HIV programs. Author.

Global Fund, The. (2020). Mitigating the impact of Covid-19 on countries affected by HIV, tuberculosis, and malaria. https://www.theglobalfund.org/ media/9819/covid19_mitigatingimpact_report_en.pdf

Human Rights Watch Country Profiles. (2020). https://www.hrw.org/videophotos/interactive/2018/04/16/sexual-orientation-gender-identitycountry-profiles 
Kelley, R. D. G. (2001). A poetics of anticolonialism. In A. Césaire, Discourse on Colonialism (pp. 7-28). Monthly Review Press.

Lorway, R. (2015). Namibia's rainbow project: Gay rights in an African nation. Indiana University Press.

Marsh, K., Eaton, J. W., Mahy, M., Sabin, K., Autenrieth, C.S., Wanyeki, I., Daher. J., \& Ghys, P.D.. (2019). Global, regional, and countrylevel 90-90-90 estimates for 2018: Assessing progress towards the 2020 target. AIDS, 33 (suppl. 3), S213-S226. https://doi.org/10.1097/ QAD.0000000000002355

McKay, T. (2016). From marginal to marginalized: The inclusion of men who have sex with men in global and national AIDS programmes and policy. Global Public Health, 11, 902-922. https://doi.org/10.1080/174416 92.2016 .1143523

Mendos, L. R. (2019). State-sponsored homophobia, 2019. International Lesbian, Gay, Bisexual, Trans and Intersex Association.

Miller, J. (1979). Caithness. Skilton and Shaw.

Miller, J. (1994). A wild and open sea: The story of the Pentland Firth. The Orkney Press.

Miller, R. L. (2020). Reducing stigma and discrimination in access to HIV health care for gay and bisexual men and transgender women using mystery patients in Cameroon and Zimbabwe. MPact Global Action for Gay Men's Health and Rights.

Miller, R. L., Rutledge, J., \& Ayala, G. (2021). Breaking down barriers to HIV care for gay and bisexual men and transgender women: The Advocacy and other Community Tactics (ACT) Project. AIDS and Behavior, 25, 2551-2567. https://doi.org/10.1007/s10461-021-03216-w

Mulé, N. L. (2018). LGBTQI-identified human rights defenders: Courage in the face of adversity at the United Nations. Gender and Development, 26, 89-101. https://doi.org/10.1080/13552074.2018.1429099

Nelson, G., \& Evans, S. D. (2014). Critical community psychology and qualitative research: A conversation. Qualitative Inquiry, 20, 158-166. 
https://doi.org/10.1177/1077800413510873

Oakley, A. (1981). Interviewing women: A contradiction in terms. In H. Roberts (Ed.), Doing feminist research (pp. 30-61). Routledge and Kegan Paul.

Ofir, Z. (2012). Foreword. African thought leaders' forum on evaluation and development: Expanding thought leadership in Africa. The Bellagio Centre.

Onapajo, H., \& Isike, C. (2016). The global politics of gay rights: The straining relations between the West and Africa. Journal of Global Analysis, $6,21-45$.

Prilleltensky, I. (2003). Understanding, resisting, and overcoming oppression: Towards psychopolitical validity. American Journal of Community Psychology, 31, 195-202. https://doi.org/10.1023/A:1023043108210

Prilleltensky, I. (2008). The role of power in wellness, oppression, and liberation: The promise of psychopolitical validity. Journal of Community Psychology, 36, 116-136. https://doi.org/10.1002/jcop.20225

Rao, R. (2014). The locations of homophobia. London Review of International Law, 12, 169-199. https://doi.org/10.1093//ril//ru010

Rogers, P. J. (2016). Understanding and supporting equity: Implications of methodological and procedural choices in equity-focused evaluations. In S. I. Donaldson \& R. Picciotto (Eds.), Evaluation for an equitable society (pp. 199-215). Information Age Publishing.

Roulston, K. (2010). Reflective interviewing: A guide to theory and practice. Sage. https://doi.org/10.4135/9781446288009

Russell, G. M., \& Bohan, J. S. (2016). Institutional allyship for LGBT equality: Underlying processes and potentials for change. Journal of Social Issues, 72, 335-354. https://doi.org/10.1111/josi.12169

Saad, L. (2017). Gallup vault: Americans slow to back interracial marriage. https://news.gallup.com/vault/212717/gallup-vault-americans-slow-backinterracial-marriage.aspx

Schlangen, R. (2014). Monitoring and evaluation for human rights organizations: Three case studies. Center for Evaluation Innovation. 
Semugoma, P., Nemande, S., \& Baral, S. (2012). The irony of homophobia in Africa. The Lancet, 380, 312-313. https://doi.org/10.1016/ S0140-6736(12)60901-5

Stauffer, J. (2015). Ethical loneliness: The injustice of not being heard. Columbia University Press. https://doi.org/10.7312/ columbia/9780231171502.001.0001

Teles, S., \& Schmitt, M. (2011). The elusive craft of evaluating advocacy. Stanford Social Innovation Review, Summer, 39-43.

Tracy, C. M. (1878). Standard history of Essex County, Massachusetts. CF Jewett \& Co.

UNAIDS. (2020a). New HIV infections increasing among key populations. https://www.unaids.org/en/resources/presscentre/featurestories/2020/ september/20200928_new-hiv-infections-increasingly-among-keypopulations

UNAIDS. (2020b). New HIV infections among gay men and other men who have sex with men increasing. https://www. unaids.org/en/resources/presscentre/featurestories/2020/ december/20201207_new-hiv-infections-increasing

UNAIDS. (2020c). Seizing the moment. Tackling entrenched inequalities to end epidemics. Author.

UNAIDS. (2021a). Global HIV AIDS statistics, Fact Sheet 2020. https://www. unaids.org/en/resources/fact-sheet

UNAIDS. (2021b). End inequalities. End AIDS. Global AIDS strategy 2021-2026. Author.

United States Department of State. (2019). Country profiles on human rights practices. https://www.state.gov/ reports-bureau-of-democracy-human-rights-and-labor/ country-reports-on-human-rights-practices/

van Wessel, M. (2018). Narrative assessment: A new approach to evaluation of advocacy for development. Evaluation, 24, 400-418. https://doi. org/10.1177/1356389018796021 
Wamai, R. G. (2014). Civil society's response to the HIV/AIDS crisis in Africa. In E. Obadare (Ed.), The handbook of civil society in Africa (pp. 361-398). Springer. https://doi.org/10.1007/978-1-4614-8262-8_21

Wilkerson, I. (2020). Caste: The origins of our discontents. Random House.

Williams, T. C. (2019). Self-portrait in black and white: Family, fatherhood, and rethinking race. W. W. Norton \& Co.

\section{The author}

Email:mill1493@msu.edu 